\title{
Research of the Role that Local University Libraries Played in the Service for the" Three Rural Issues"
}

\author{
Gemin Li \\ Jilin Agricultural University Library \\ Jilin, China 130118
}

\begin{abstract}
China, being an agricultural country, long in her history, has been underscoring the important role of the three rural issues: agriculture, rural areas and farmers. In the modern society, agricultural university libraries should play an important factor in service for the three rural issues in order to strengthen the construction of the three rural issues, due to their advantage.
\end{abstract}

Keywords-service for the three rural issues; agricultural colleges or universities; the duty and role of libraries

\section{INTRODUCTION}

"Three rural issues" is the full capsule of China's present rural social, economic, and other aspects. We believe that the sufficient use of the agricultural university libraries should be a very effective way if we want to give a better answer to the problem of agriculture, rural areas and farmers.

Agricultural university libraries have both rich information resources and human resources, and they are also the powerful driving force of elevating the construction of the three rural issues. During promoting the construction of the three rural issues, the involved departments should put the true and up-to-date situation of our country's agriculture, countryside and farmers together. Only by that can we make utmost use of the advantages of agricultural libraries, and positively create more new ways and methods to fulfill the agriculture college libraries' destiny in the service of the three rural issues, thus ultimately playing a greater role in the process, so as to continuously improve the farmers' income, agricultural efficiency and the long term development of agriculture.

\section{THE STRENGTH OF AGRICULTURAL UNIVERSITY}

LIBRARIES’ IN PROMOTING THE THREE RURAL ISSUES

Compared with general colleges and universities, the agriculture college libraries have more strength in their personnel, infrastructure, and also the collection resources. Therefore, these strengths should be made full use of as to play them as the trump card in the construction of the three rural issues. All in all, the strengths mainly include the following two points.

\section{A. The Strengths of the Collection Resources}

As we all know, agricultural universities have very wealthy resource in agricultural science and education: they have related paper resources, and a good deal of electronic resources (based on the network environment), and also the libraries can provide images, video, data, patents, newspapers, periodicals, books and other various types of information, especially when there is interlibrary cooperation between colleges and universities, the libraries will have much richer information resources.

Many agricultural colleges and universities libraries have installed a sole and fairly complete library system to meet the demands of the students and subject development, For example, the Qingdao Agricultural University considered the practical condition of Shandong Province as to pile tens of thousands of kinds of video materials on agricultural economic management, agricultural machinery, technology and pest management, food processing and animal husbandry and veterinary. As to meet the needs of the departments, the university has also equipped Qingdao agriculture technology communication service network [1].

\section{B. The Strength of the Personnel Resources}

Agricultural university libraries usually have a professional technical personnel with agricultural science related professional background and high academic level and good information service ability, who can be the farmers' information receptors and liaison between all kinds of literature and information resources. Besides, the agricultural colleges and universities have agricultural majored lecturers and professors, also a huge number of leaders who are rich in agricultural theoretical knowledge and practical experience, which makes them qualified to be the powerful technical support for agriculture, rural areas and farmers' services.

\section{The AgricUlture UNIVERSITY LibRARIES' SER VICE TO AGRICULTURE, RURAL AREAS AND FARMERS}

\section{A. To Widen the Scope of Service, and Reinforce the Service Function}

In theory, upon various advantages above, the agricultural university libraries should be the critical factor to provide service to agriculture, rural areas and farmers, but actually, university libraries, for the most part, are in big cities--far from the rural areas and farmers, which results very low conversion rate between scientific research and agricultural achievements. The agricultural university libraries that have possessed a large quantity of agricultural 
information should be open to the wide rural areas, farmers and should expand its service scope. Only by this method, can they turn their agricultural information advantage a radioactive role to provide true service to agriculture, rural areas and farmers. If we want to provide better service for agriculture, rural areas and farmers, the libraries should construct the "subject librarian - professor figure feeling" mode to deeply study and explore the recommendation and evaluation of the literature, electronic resources utilization, as well as topic tracking, and the subject navigation in conducting counterpart service departments in the libraries.

\section{B. To Strengthen the Construction of Information Resources}

It is one of the duties for agricultural university libraries to provide better service for agriculture, rural areas and farmers, thus underscoring the great importance to the construction work so as to strengthen the construction of agricultural information resources will be essential. Here we suggest some ways that we think effective, and they are: we think it a good way to increase investment to buy more agricultural books and periodicals, collect different years published agricultural books and periodicals, and the construct large dense stacks to put agricultural books together to bring convenient to a great extent for school teachers and students and farmers friends to refer to. Besides purchasing the paper literature resources in large quantities, universities also should choose a Chinese-foreign database and electronic books, which will provide the agriculture, rural areas and farmers more comprehensive and more abundant information service ${ }^{[2]}$.

\section{To Bring the Science and Technology to the Countryside}

It is necessary for the agricultural university libraries to make full use of their own advantages to provide information to the countryside, where farmers need agricultural science and technology to have the access to information, and we believe that the comprehensive and popular science literature and understanding the current new technology are the key for peasants to improve in-all quality in time.

\section{Promoting Agricultural Professional College Students' Ability to Information Retrieval and Information Use}

Experts should be specially selected by the libraries and sent to some poor mountainous areas to work as agriculture technology instructors to help local farmers to fight poverty and try to be a bridge and link between farmers and science and technology. Other than providing peasants with agricultural science and technology, the experts should also give feedback to the school libraries, and in turn, the libraries should collect, analyze and summarize the feedback information and distribute it to every peasant via popular science booklets.

For the students who major in agricultural, the university libraries should give them regular training of library knowledge, trying to teach them how to retrieve and utilize library information. The libraries can prepare related courses such as information retrieval and information use, if necessary to teach the students how to use the Chinese- foreign database retrieval, and how to collect and process and sorting information, which will pave a sturdy foundation for the students to have the ability to provide better service for agriculture, rural areas and farmers after they graduate.

\section{E. Construction of Modern Library}

We have to admit that China's scientific and technological achievements conversion rate is not high compared with many developed countries, so it is very hard for some remote rural area to understand new technology and new achievements in time. In this case, Agricultural university libraries that are abundant in information resources should strengthen the construction of modernization. We think they can promote agricultural technology and disseminate knowledge by providing agricultural science and technology manuals or by making them into video to play in the vast countryside in the specified seasons when farmers purchase agricultural machinery and implements, and township personnel can irregularly organize farmers to watch the libraries' online websites to help the huge number of farmers to master new knowledge of agriculture in shorter time. Agricultural universities should also invest enough amount of money to construct digital and network, and to improve the normalization, standardization and scientific management of school libraries, so as to fulfill more complete functional school libraries with more characteristics, and better quality, which will finally better meet the demands of rural construction and development of information technology ${ }^{[3]}$. Therefore, it is of great significance for the library in colleges and universities to modernize.

\section{F. Building Joint Local Library Services for the League to Agriculture, Rural areas and Farmers}

The university libraries should centralize themselves when in driving the area, especially, the remote and rural libraries' construction and development. The three-ruralservice alliance can be fully formed by combining the local libraries with rural libraries via this means dynamic service can be adopted, which will help information science and technology to become richer. Moreover, the university libraries should also work with some local business firms such as aquaculture, animal husbandry, chemical fertilizer, seeds and institutions as agricultural scientific institutes and county association for science and technology to make information service network to become all-round service for agriculture, rural areas and farmers ${ }^{[4]}$

\section{CONCLUSION}

Agricultural university libraries's advantages on collection resources and talent resources should be made full use of to do a better job in the following six aspects, which are:

- to expand the scope of service;

- to strengthen the service function;

- to strengthen the construction of information resources; 
- to carry out the science and technology to the countryside and

- develop agricultural professional college students' ability of information retrieval and information use;

- to strengthen the construction of modern library and to combine local library building common services.

Agricultural university libraries will still have to research and explore more new means and methods to provide better service for agriculture, rural areas and farmers, and promote better and faster development for the three-rural-issues.

\section{REFERENCES}

[1] PAN Mei. Importance and Measures of Library of Agricultural University in Developing Rural Area [J] Hubei Agricultural Sciences, 2009, 48 (3): 766-768.

[2] Li Hejuan, Hui Qing, He Yanhui, The New Ways of Agricultural University Library Serves for "Three Rural" [J] Chinese Countryside Well-off Technology, 2010 (7): 11-12.

[3] MA Xiu-wen, LI Yong-guo. Bring into Full Play the Advantages of Agricultural Libraries to Make Greater Contribution in Solving "Three Agriculture" Issues [J] Journal of Library and Information Sciences in Agriculture, 2010, 22 (6): 201-202.

[4] DIAO Zhi-kai. Discussion on Agricultural University Libraries Serving for peasant, rural areas and agricultue [J] Modern Agricultural Science and Technology, 2009 (16): 395-396. 